\title{
Mechanical Forces Impair Alveolar Ion Transport Processes - A Putative Mechanism Contributing to the Formation of Pulmonary Edema
}

\author{
Martin Fronius \\ Institute of Animal Physiology, Justus-Liebig-University Giessen
}

Germany

\section{Introduction}

The aim of this chapter is to highlight the importance of transepithelial ion transport processes for lung function in general and to focus on the impact of mechanical forces on pulmonary ion transport in particular. Linking mechanical forces with pulmonary ion transport derives from the fact that the lung is a dynamic organ as well as from several studies providing evidence that the amount of mechanical forces as used during artificial ventilation correlates with mortality rates in patients with respiratory failure such as ALI (acute lung injury) and ARDS (acute respiratory distress syndrome) (ARDS Network Investigators, 2000). In these patients the formation of pulmonary edema is a characteristic symptom (Frank and Matthay, 2003; Ricard et al., 2003) and the basic rationale behind this is, that mechanical perturbations cause epithelial leakage in response to mechanically induced damage of the epithelial layer. This damage is suggested to be a major cause for the formation of pulmonary edema as well as the inability to reabsorb the edema fluid. However, little is known whether or not mechanical forces may directly interfere with pulmonary ion transport processes and this represents a putative mechanism that facilitates the formation of pulmonary edema - in addition to damages of the epithelial layer.

\section{Air breathing and pulmonary ion transport}

The water land transition of tetrapods represents a fundamental process within vertebrate evolution that was accompanied by the development of lungs as gas exchanging structures. The major advantage of air breathing is the almost infinite access to oxygen, although this bears also some risks. The gas-exchanging structures must be moistened to facilitate oxygen solubility and the architecture of these structures must be adapted to the requirement of efficient gas exchange by diffusion. These problems were basically fixed by invagination of the gas-exchanging surface, protecting them from desiccation and from mechanical damage. Therefore, invagination could be considered as a basic improvement allowing the development of a highly conserved architecture of the air blood barrier that can be found within all air-breathing vertebrates. This architecture is referred to as the "three ply design" (Maina and West, 2005). The three layers of the air-blood barrier are represented by the 
pulmonary epithelium, the basal lamina and the endothelium that forms the pulmonary capillaries. Although invagination and the development of the three ply design fixed a lot of problems, other challenges arose. To ensure a constant supply of oxygen as well as a continuous replacement of the breathing medium, ventilation mechanisms were needed. This was achieved by different strategies within the different vertebrate classes. Early tetrapods and amphibians ventilate their lungs by a buccal pump (Brainerd and Owerkowicz, 2006). In higher vertebrates ventilation occurs by a costal pump (Roux, 2002) where the movement of the ribs ensures aspiration of air. But independent of the strategy how the exchange of the breathing medium is accomplished, the gas-exchanging surface is permanently exposed to pollutions and pathogens that are omnipresent in the air supplied to the lungs.

It is also well known that the entire pulmonary epithelium is covered by a thin fluid layer (PLL: pulmonary liquid layer) (Daniels and Orgeig, 2003), that is of particular importance for the function of the lung. The PLL extends from the distal parts of the lung to the upper airways and consists of mucus, surfactant and periciliary fluid (Rubin, 2002) (Fig. 1). On the one hand the PLL is the first physical border that is exposed to the environment and the first line of host defense that absorbs pathogens. This is of particular importance in the airways, where the PLL is part of the innate immune system and crucial for protecting the host from the permanent exposure to pollutions and pathogens due to their removal by the mucociliary clearance (Welsh, 1987; Davis and Lazarowski, 2008).

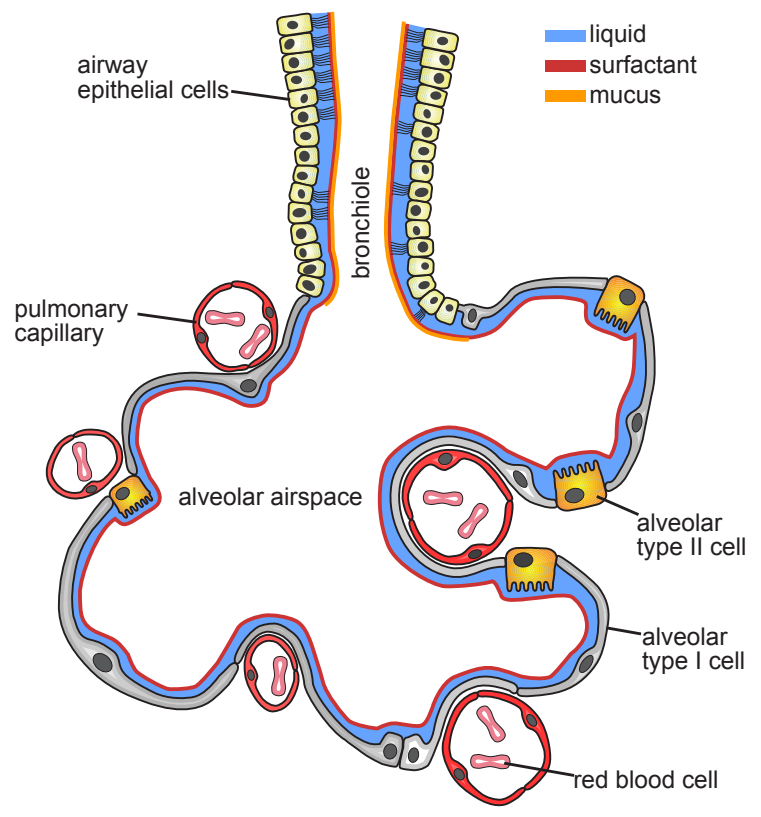

Fig. 1. Schematic drawing of the distal lung region. The distal lung is represented by respiratory bronchioles and terminal alveoli that are lined by a continuous layer of epithelial cells consisting of different cell types. The entire epithelium is further covered with a liquid film (PLL: pulmonary liquid layer) consisting of different layers. In the airways the PLL is composed from a liquid layer (periciliary fluid) and a layer of mucus and surfactant. In the alveolar regions the PLL consists of a liquid layer (alveolar fluid) and a surfactant layer. 
On the other hand the height and volume of the PLL in the respiratory zone - primarily represented by the alveolar fluid - determines the distance of diffusion for the gases that is a limiting rate for the diffusion efficiency as defined by Fick's law of diffusion. Thus, increased fluid content in the alveolar region decreases oxygenation of the blood (Matalon and O'Brodovich, 1999; Matthay et al., 2000).

Therefore, the consistency as well as the volume of the PLL layer must be tightly regulated and controlled - in the airways as well as in the gas-exchanging region - to ensure effective host defense as well as effective gas exchange.

This principle becomes evident regarding pulmonary diseases that are associated with inappropriate fluid balance in the lung. For example hyperabsorption of water from the airspace increases the viscosity of the PLL and this interferes with the removal of inhaled pathogens due to impaired mucociliary clearance as observed in patients with cystic fibrosis (Fig. 2A) (Widdicombe et al., 1985; Riordan et al., 1989; Matsui et al., 1998). In contrast, too much fluid in the lung impairs gas diffusion and this can be observed in patients with pulmonary edema (Figure 2B) (Sznajder, 2001; Hoschele and Mairbaurl, 2003).

Thus, a defined content of water covering the pulmonary epithelia is a basic requirement for proper lung function and this depends on the development of appropriate ion transport processes accomplished by the pulmonary epithelia.

A

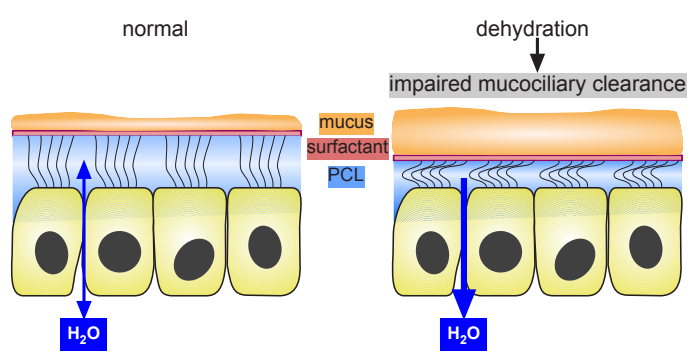

B

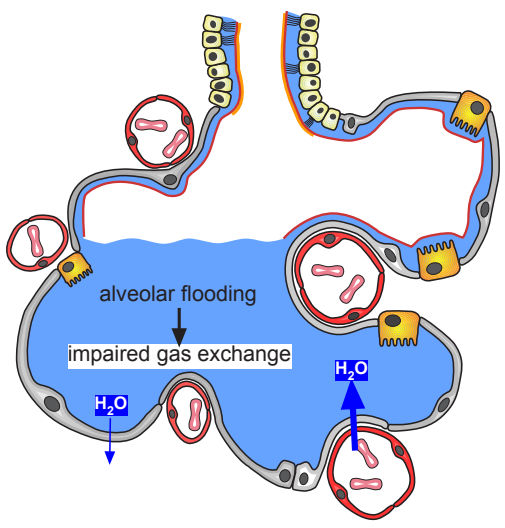

Fig. 2. Impaired epithelial fluid transport affects basic lung functions. A) Increased water reabsorption in the airways results in dehydration of the periciliary liquid layer (PCL) leading to an impaired mucociliary clearance and mucus accumulation within the airways. B) In the alveolar region an imbalance between fluid reabsorption and fluid infiltration leads to the formation of pulmonary edema that impairs the exchange of the breathing gases.

\subsection{Transepithelial $\mathrm{Na}^{+}$and $\mathrm{Cl}^{-}$transport are the main pathways to control the water content in the lung}

Studying ion transport processes across pulmonary epithelia within the last decades improved our understanding how the fluid content in the lung is sustained. The basic principle of pulmonary water transport is ubiquitous - ions are transported across the epithelial layer and this generates transepithelial osmotic gradients that cause water diffusion across the epithelium (Sackin and Boulpaep, 1975). It is well accepted that 
pulmonary epithelia are $\mathrm{Na}^{+}$reabsorptive epithelia where active $\mathrm{Na}^{+}$reabsorption represents the bulk of transepithelial ion transport. $\mathrm{Na}^{+}$transport occurs via two steps: 1) $\mathrm{Na}^{+}$ions are taken up through epithelial $\mathrm{Na}^{+}$channels $(\mathrm{ENaC})$ at the luminal side of the epithelial cells and are pumped out from the cells at the basolateral side by the $\mathrm{Na}^{+} / \mathrm{K}^{+}$ATPase. This process is suggested to be the principle mechanism for water reabsorption from the airspace into the body (Matthay et al., 2002). Another major component with significant impact on transepithelial water movement is represented by the transepithelial transport of $\mathrm{Cl}^{-}$. In the airways it is well accepted that $\mathrm{Cl}^{-}$is secreted via luminal $\mathrm{Cl}^{-}$channels (Smith et al., 1982; Willumsen et al., 1989; Chambers et al., 2007). However the particular role of $\mathrm{Cl}^{-}$channels $\mathrm{Cl}^{-}$in alveolar epithelial cells remains unclear since there is evidence that $\mathrm{Cl}^{-}$is secreted (McCray et al., 1993; Tizzano et al., 1994; Lazrak et al., 2002; Sommer et al., 2007), as well as absorbed (Fang et al., 2002; Fang et al., 2006). There are at least two different $\mathrm{Cl}^{-}$channels identified in the apical membrane of pulmonary epithelial cells - the $\mathrm{Ca}^{2+}$ dependent $\mathrm{Cl}^{-}$channel (TMEM16a) (Caputo et al., 2008; Schroeder et al., 2008; Yang et al., 2008) and the cAMP dependent CFTR Cl- channel (Riordan et al., 1989; Welsh and Smith, 1993). In addition it might be noted that alveolar epithelial cells are characterized by a high water permeability (Folkesson et al., 1994; Dobbs et al., 1998) although the role of these proteins in pulmonary fluid handling is uncertain since no significant impact of aquaporins on alveolar clearance has been detected in transgenic (aquaporin deficient) animals (Verkman et al., 2000; Verkman, 2007).

However, the crucial importance of defined and regulated ion transport processes in the lung to control the water content is beyond dispute, since this was impressively confirmed by several studies using transgenic animal models with impaired ion channel functions. For example deletion of the $\alpha \mathrm{ENaC}$ subunit in mice leads to early death due to the inability to reabsorb the alveolar fluid from the lungs after birth (Hummler et al., 1996). Interestingly, rescuing $\alpha \mathrm{ENaC}$ expression in transgenic mice that were derived from $\alpha \mathrm{ENaC}$ deficient mice demonstrated that these animals expressed decreased levels of ENaC mRNA and that this resulted in an increased susceptibility to the formation of pulmonary edema (Olivier et al., 2002). In addition overexpression of the $\beta \square \mathrm{ENaC}$ subunit and hyperabsorption of $\mathrm{Na}^{+}$is associated with impaired mucociliary clearance resulting in a phenotype that is characteristic for cystic fibrosis (Mall et al., 2004). Recent studies established that mutations in the CFTR gene of pigs resulted in a cystic fibrosis like lung disease (Rogers et al., 2008; Stoltz et al., 2010).

\section{Mechanical forces and breathing}

Ventilation of the lungs due to the movement of the chest is associated with the appearance of physical forces. These forces are pressure (force per area), strain (deformation e.g. reasoned by the impact of pressure) and shear stress (movement of fluid at the cellular surface) (Fig. 3) (Wirtz and Dobbs, 2000). It might also be considered that due to the complex anatomy of the gas exchanging area it is difficult to estimate the distinct forces acting on individual cells (Liu et al., 1999) and that the local appearance of forces can be influenced by parameters like surfactants, focal adhesion molecules, the contractile machinery of the cells as well as the activity of molecular motor proteins within the cells (Fredberg and Kamm, 2006).

Although more or less all cell types within the lung are exposed to these physical stimuli the following section will focus on epithelial cells. Especially, the appearance and the reason for the stimuli as well as their impact on the pulmonary epithelial cells will be discussed. 


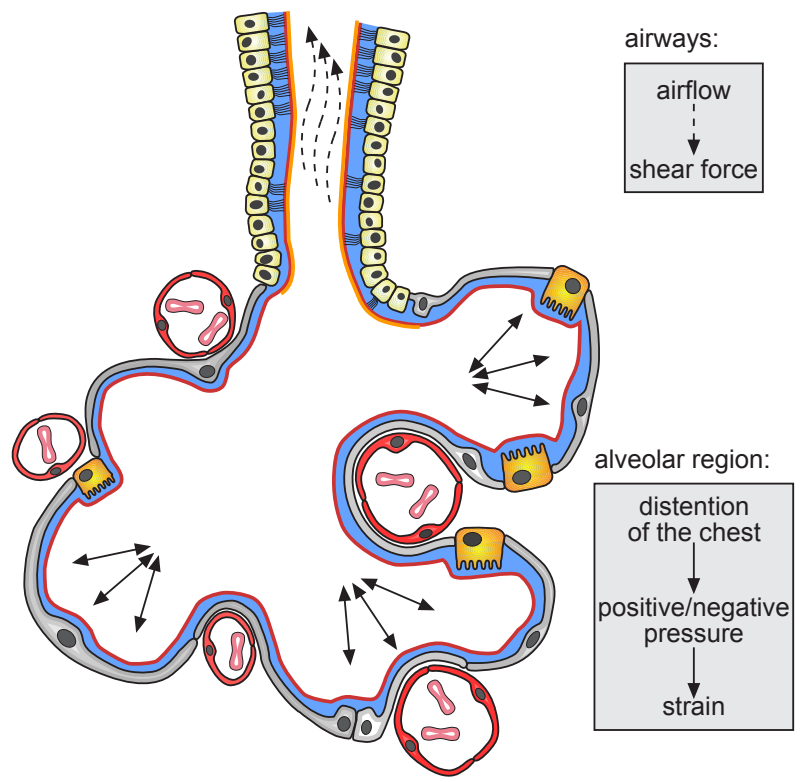

Fig. 3. Breathing is associated with the appearance of physical forces. Airway epithelial cells are primarily exposed to shear forces that are reasoned by the airstream flowing passing the surface of the airways. In the alveolar region the main physical force is strain due to the positive and negative pressure that are reasoned by the movement of the chest.

\subsection{Pressure and strain in the lung}

The appearance of pressure is the consequence of the movement of the chest. During inspiration and expiration epithelial cells are exposed to negative and positive pressures. This pressure is defined as transpulmonary pressure and resembles the pressure difference between the pressure in the pleural space and the atmospheric pressure (Fredberg and Kamm, 2006). During inspiration at rest the inflating pressure is approx. $5 \mathrm{~cm} \mathrm{H}_{2} \mathrm{O}$ and this can increase to approx. $30 \mathrm{~cm} \mathrm{H}_{2} \mathrm{O}$ at deep inspirations (Fredberg and Kamm, 2006). In the lung the appearance of pressure will always cause deformation of the cells due to the delicate anatomy and morphology of the alveolar structure. Therefore, increasing pressure is always associated with the appearance of strain. From this point of view, it seems obvious to consider that strain rather than pressure is the adequate stimulus acting on epithelial cells as a consequence of the breathing movements (Liu et al., 1999).

\subsection{Shear stress in the lung}

In addition to strain, the luminal surface of the epithelial cells is exposed to shear stress. Shear stress is defined by the tangential movement of particles (e.g. air or fluid) at the surface between different physical compartments. In the airways shear stress is primarily caused by the oscillating airflow passing the surface of the airway epithelial cells (Tarran et al., 2006). In the distal lung regions shear stress is a consequence of the movement due to distention, where the epithelial cell represents one compartment that is distended and the fluid of the PLL represents a static component of another compartment. Thus a relative 
movement of the epithelial cell (with respect to the fluid) will cause shear stress at the luminal surface of the cells.

The next sections will focus on the impact of pressure and strain in particular on lung functions.

\subsection{Strain is crucial for several functions of epithelial cells}

It is well known that physical forces are important stimuli for distinct cellular functions of pulmonary epithelial cells (Fig. 4). An important indication for this is represented by the fact that development of the mammalian lung within the last third of gestation depends on breathing movements although the lungs are fluid filled (Kitterman, 1996). In animal models prevention of these breathing movements by spinal nerve sections resulted in retarded lung growth and development (Fewell et al., 1981). Further, in vitro studies demonstrated that distention of alveolar epithelial cells is an important trigger that affects alveolar cell differentiation. Mechanical distention of isolated and cultivated fetal alveolar cells promotes their differentiation to AT I cells whereas that lack of distention promotes the differentiation to ATII cells (Edwards, 2001).

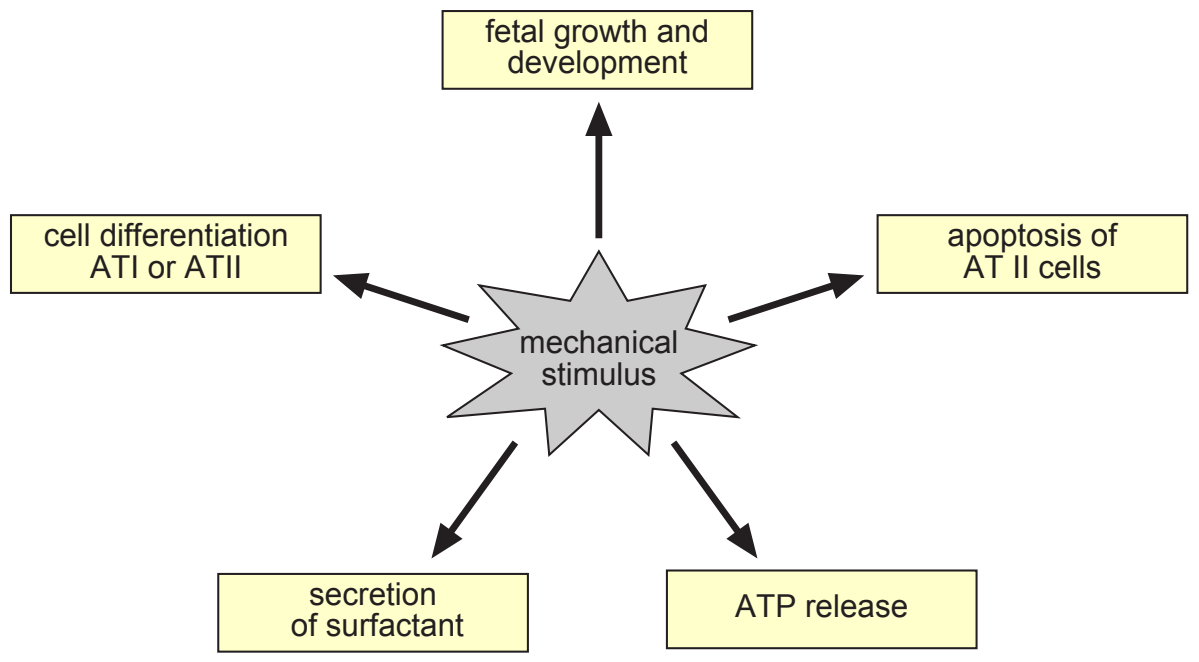

Fig. 4. Under normal breathing conditions mechanical stimuli are important for several functions of the lung.

Besides affecting cell differentiation and lung development there is also evidence for the contribution of physical stress as a factor that mediates production and secretion of surfactant proteins by ATII cells (Edwards et al., 1999) as well as by cultured H441 cells (Sanchez-Esteban et al., 1998). There is also evidence that mechanical forces induce apoptosis in ATII cells (Edwards et al., 1999; Hammerschmidt et al., 2007). In addition, different signaling mediators and ATP in particular are released in response to mechanical stress (Homolya et al., 2000; Okada et al., 2006; Button et al., 2007). The release of ATP offers the possibility to initiate a variety of different cellular reactions by acting on multiple purinergic receptors - including P2X, P2Y and P1 receptors (Leipziger, 2003; Bucheimer and Linden, 2004; Barth and Kasper, 2009). The relevance of purinergic signaling has been 
implicated by a study identifying alterations of transepithelial ion transport processes in airway epithelia in response to adenosine as a factor contributing to cystic fibrosis lung disease (Tarran et al., 2005; Tarran et al., 2006).

\subsection{Deleterious effects of mechanical forces in the lung}

Although, there is more than sufficient evidence that identifies mechanical stimuli as an important mediator for normal lung functions, a main reason for studying their effect in the lung arises from the hazardous effects that are caused by mechanical forces during artificial ventilation (Frank and Matthay, 2003; Ricard et al., 2003) (Fig. 5).

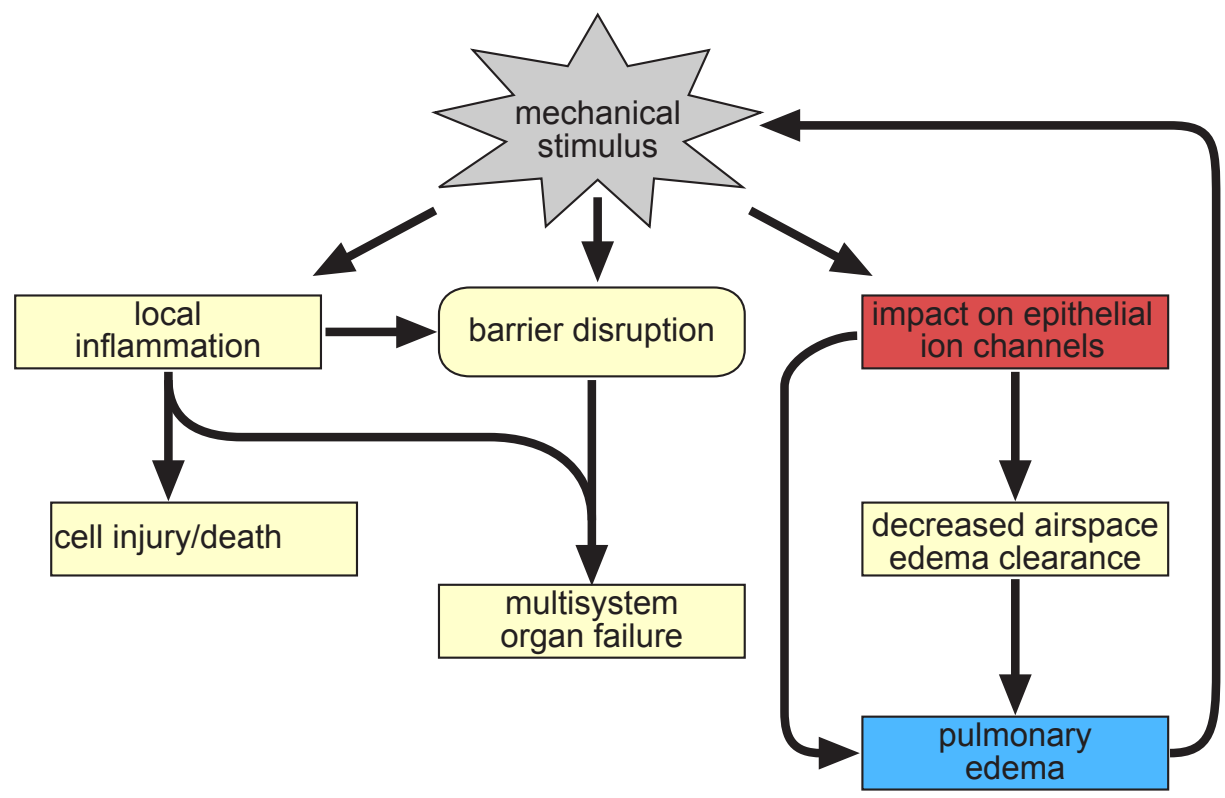

Fig. 5. Effect of deleterious physical forces related to ventilator induced lung injury. This scheme was modified from (Frank and Matthay, 2003) and extended by the potential interference of mechanical stimuli with the activity of epithelial ion channels. This represents a yet unidentified mechanism to improve the understanding how mechanical forces contribute to the formation and probably maintenance of pulmonary edema.

Artificial ventilation is a remedy of first choice for the treatment of patients with respiratory failure (e.g. acute lung injury (ALI); acute respiratory distress syndrome (ARDS)) (Ware and Matthay, 2000). However, the development of pulmonary edema due to fluid influxes into the airspace as well as the inability to resolve the edema fluid by decreased fluid reabsorption, is a major reason for the morbidity and mortality in these patients (Morty et al., 2007). The inability of the patients to resolve the edema fluid correlates with the mechanical ventilation duration times and mortality. High fluid clearance was associated with shorter durations of mechanical ventilation as well as with significantly decreased mortality rates (Sznajder, 2001; Ware and Matthay, 2001).

Considering the important role of pulmonary ion transport processes as discussed above, it is obvious that pulmonary edema are somehow related to alterations of pulmonary ion 
transport processes (Matthay, 2002). Although changes of ion transport processes do not have to be causative for the development of pulmonary edema - there is sufficient evidence demonstrating that artificial ventilation worsens the situation in ALI/ARDS patients. This phenomenon has been termed ventilator induced lung injury (VILI) (Ricard et al., 2003) and is attributed to inappropriate ventilation strategies and thus the appearance of extensive physical forces (Fig. 5) (Plataki and Hubmayr, 2010).

This indication arises from the outcome of a multicenter trail study demonstrating a significantly reduced mortality in a group of patients that was ventilated with decreased tidal volumes $(6 \mathrm{ml} / \mathrm{kg})$ compared with high tidal volumes $(12 \mathrm{ml} / \mathrm{kg}$ ) (ARDS Network Investigators, 2000). Ventilation with decreased tidal volumes was also accompanied by the appearance of lower plateau pressures (ARDS Network Investigators, 2000) and this is associated with decreased mechanical forces.

However, regarding the symptoms observed in patients with ALI, ARDS and VILI there is an obvious connection between artificial ventilation and the development of pulmonary edema. There are two possible explanations reasonable for the development of pulmonary edema related to artificial ventilation:

1. Artificial ventilation causes ruptures and damages of the epithelial layer - enabling an uncontrolled influx of protein rich fluid into the airspace.

2. Mechanical forces as appearing during ventilation directly interfere with pulmonary epithelial ion transport processes

The first point has been extensively studied and there is no doubt that mechanical strain induced by artificial ventilation is a major reason for the development of pulmonary edema (Frank and Matthay, 2003). This is clearly indicated by the appearance of proteins in the edema fluid (Ware and Matthay, 2000). The second point is also obvious since a correlation between the ability to reabsorb alveolar fluid and the outcome of patients has been identified (Ware and Matthay, 2001). But for this instance, the mechanisms how artificial ventilation and thus mechanical forces interfere with ion transport processes are unknown.

\subsection{Tools for studying the impact of mechanical forces on pulmonary ion transport}

The first choice for studying functional epithelial ion transport is represented by electrophysiological Ussing chamber recordings. This technique was established by Hans Ussing during his studies on ion transport processes across the amphibian skin (Ussing and Zerahn, 1951). A major advantage as well as a prerequisite of this technique is the use of an intact epithelial layer consisting of differentiated polar cells. Although this technique is applicable for many freshly dissected epithelia including airway epithelia from mammals (Olver et al., 1975; Widdicombe and Welsh, 1980), the use of mammalian alveolar epithelium for elaborating this technique is not possible. This is due to the complex anatomy reasoned by miniaturization of the gas-exchanging region. Improved protocols and procedures for the isolation and cultivation of alveolar cells generally fixed this problem, but the use of isolated cells bears the risk of using cells with an artificial non-physiological phenotype. There is a bunch of studies published demonstrating that in isolated and cultivated cells the expression of ion transport proteins as well as their phenotype in terms of ion transport properties vary in dependence of the cultivation conditions used (Kunzelmann et al., 1996; Jain et al., 2001; Leroy et al., 2004; Dvorak et al., 2011). Further, these cells do not have their native surrounding (neighboring cells of different cell type, basal lamina etc.) that is important for the detection and transmission of forces. It remains also a challenge to expose these cultivated cells to defined physical forces (e.g. strain) to determine immediate changes 
of ion transport processes because usually the cells are cultivated on rigid polyester or polycarbonate membranes.

On the other hand pioneer studies addressing the function and relevance of pulmonary ion transport were performed on anaesthetized animals (Egan et al., 1976; Matthay et al., 1982). These studies identified the basic mechanisms of water and electrolyte transport by the alveolar epithelium. However, from such studies it is difficult to disentangle the particular ion conductances and to identify the specific ion transporting molecules that are involved in those processes.

\subsubsection{Using native lung preparations for studying the impact of strain on pulmonary epithelial ion transport}

Our lab has therefore established a native model for investigations of pulmonary ion transport. In accordance to Krogh's principle (Krebs, 1975) we decided to use lung preparations derived from the South African Clawed Frog Xenopus laevis. The alveolar epithelium of the Xenopus lung consists of one cell type referred to as pneumocytes (Meban, 1973). The anatomy and morphology of these cells is reminiscent to that of alveolar type I cells (Fischer et al., 1989), but they expose functional properties of alveolar type II cells as represented by the presence of lamellar bodies (Fischer et al., 1989). Most important, the Xenopus pneumocytes expose a $\mathrm{Na}^{+}$reabsorptive phenotype (Fischer et al., 1989; Kim, 1990; Fronius et al., 2003). In addition, expression and function of the CFTR Cl- channel has been detected (Sommer et al., 2007). Recent studies identified the presence of the $\mathrm{Na}^{+} / \mathrm{K}^{+} / 2 \mathrm{Cl}^{-}$ cotransporter, the function of a $\mathrm{HCO}_{3}-/ \mathrm{Cl}^{-}$exchanger (Berger et al., 2010) and evidence for basolateral $\mathrm{Cl}^{-}$channels (Berger et al., 2011). Thus, the Xenopus pneumocytes exhibit the basic repertoire of ion channels and transporters that are supposed to be important in mediating the volume of the PLL.

The main advantage of this amphibian organ is its relatively simple sac-like structure. This feature is a prerequisite for dissecting a preparation that is suitable for Ussing chamber recordings. Comparable studies with other native lung preparations from higher vertebrates - and mammals in particular - are not possible, because of the growing complexity and miniaturization of the gas-exchanging region. In addition to establishing the use of Xenopus lung preparations for electrophysiological recordings, an Ussing chamber was developed that enables the exposure of the mounted pulmonary epithelium to mechanical forces. Mechanical forces are applied via an increased hydrostatic pressure and this is achieved by changing the outflow-height from the compartments Fig. 6.

\section{Impact of strain on pulmonary ion transport in the Xenopus lung}

Although the connection between high tidal volumes and pulmonary edema has been well established, little is known whether or not the underlying mechanisms can be attributed - at least partly - to a direct interaction of the mechanical forces with ion transport processes. Studies have been published providing evidence that high volume ventilation resulted in a decreased $\mathrm{Na}^{+}$transport due to a decreased $\mathrm{Na}^{+} / \mathrm{K}^{+}$-ATPase activity (Lecuona et al., 1999). Other studies demonstrated an increased $\mathrm{Na}^{+} / \mathrm{K}^{+}$-ATPase activity in response to cyclic stretch (Fisher and Margulies, 2002). Although these studies identified interference of strain with $\mathrm{Na}^{+} / \mathrm{K}^{+}$-ATPase activity, changes were observed hours after exposure to mechanical forces. So far little is known about a direct short-term effect of mechanical forces on ion transport processes in the lung. 


\section{customized Ussing chamber}
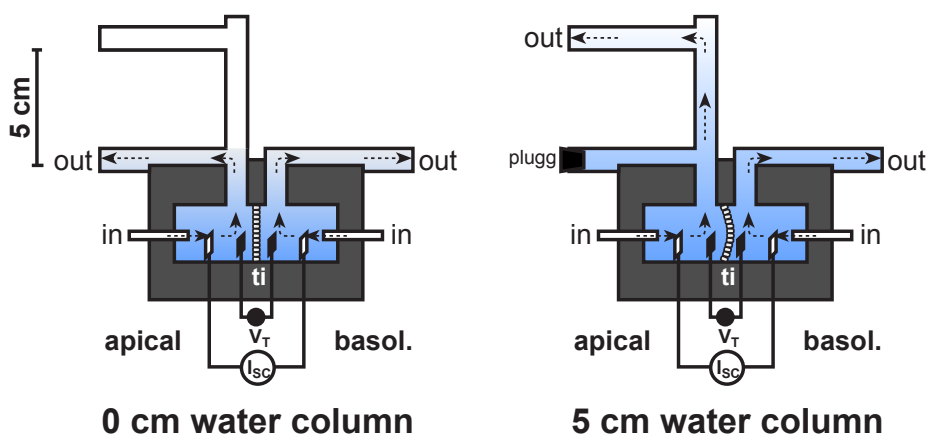

Fig. 6. Drawing of the Ussing chamber used to study the effect of mechanical forces on pulmonary epithelial ion transport (modified from (Bogdan et al., 2008)). Mechanical forces were applied by increasing the water column ( $5 \mathrm{~cm}$ water column) of the outflow. Both chamber compartments (apical, basolateral) were continuously perfused and the transepithelial short-circuit current ( $\left.\mathrm{I}_{\mathrm{SC}}\right)$ and potential $\left(\mathrm{V}_{\mathrm{T}}\right)$ was permanently monitored (ti: mounted tissue).

Using Xenopus lung preparations in combination with a customized Ussing chamber (Fig. 6) $5 \mathrm{~cm}$ hydrostatic pressure was applied from the apical side to mechanically challenge the tissue. Application of hydrostatic pressure was accompanied by immediate changes of the measured transepithelial short-circuit current (Isc). The net effect induced by $5 \mathrm{~cm} \mathrm{H}_{2} \mathrm{O}$ was characterized by a decreased transepithelial current (Bogdan et al., 2008). Interestingly, the application of $5 \mathrm{~cm} \mathrm{H}_{2} \mathrm{O}$ from the basolateral side induced exactly the same response whereas the application of $5 \mathrm{~cm} \mathrm{H}_{2} \mathrm{O}$ synchronously from the apical and basolateral side did not cause any effect of the ISC (Bogdan et al., 2008). These observations clearly demonstrate that the effective mechanical stimulus is strain and that it does not matter from which side the tissue is deflected.

In this setup a decreased transepithelial ion current is an indication for a decreased net reabsorption of ions from the apical to the basolateral side of the epithelium. Further, a reduced ion reabsorption reasoned by changes in ion transport processes will also reduce the osmoticaly driven water reabsorption from the airspace. This means that the changes of ion transport in the pulmonary epithelium observed with hydrostatic pressure decrease water reabsorption from the airspace and this represents a mechanism to facilitate the development of pulmonary edema - without affecting the integrity of the epithelial barrier that was assessed by determining the transepithelial electrical resistance.

\subsection{Strain induces short-term activation of $\mathrm{Na}^{+}, \mathrm{K}^{+}$and $\mathrm{Cl}^{-}$channels}

Further investigations using different ion channel inhibitors and substituting different ions from the perfusion solution revealed that the observed effect is reasoned by the activation of different ion channels and ion conductances resembled by:

1. activation of amiloride-sensitive $\mathrm{Na}^{+}$reabsorption

2. activation of an apical $\mathrm{Cl}^{-}$secretion 
3. activation of an apical $\mathrm{K}^{+}$secretion

Therefore, the inhibitory effect observed in the absence of drugs is an overlay of these three conductances (Fig. 7). Activation of $\mathrm{Na}^{+}$reabsorption as well as an increase of $\mathrm{Cl}^{-}$secretion will produce an increase of the ISC. In contrast to this, activation of apical $\mathrm{K}^{+}$channels will cause a decrease of the ISC. Since the net pressure effect is an inhibition of the ISC, the major response observed by the application of hydrostatic pressure is due to an activation of apical $\mathrm{K}^{+}$channels. Accordingly, the inhibitory effect of hydrostatic pressure should be prevented (or reversed $\rightarrow$ activation of the $\mathrm{I}_{\mathrm{SC}}$ ) following pre-incubation with $\mathrm{K}^{+}$channel inhibitors. And indeed this is exactly what we observed (Bogdan et al., 2008). Further, it has been found that the pressure-induced effect was largely prevented by glibenclamide (Bogdan et al., 2008), a compound that is a high affinity inhibitor of ATP-sensitive $\mathrm{K}^{+}$channels $\left(\mathrm{K}_{\mathrm{ATP}}\right)$ (Nichols, 2006). Among other activating mechanisms, the activity of $K_{A T P}$ channels is dependent on intracellular cyclic nucleotide levels and ATP in particular (Nichols, 2006). Interestingly, increased extracellular ATP concentrations were observed in response to the application of hydrostatic pressure and this represents a likely mechanism to explain our observations.

$\mathrm{K}_{\text {ATP }}$ channels are octameric complexes consisting of four pore forming Kir (inward rectifying $\mathrm{K}^{+}$channels) subunits and four associated SUR (sulfonylurea receptor) subunits (Nichols, 2006). In particular Kir channels are supposed to be involved in controlling the

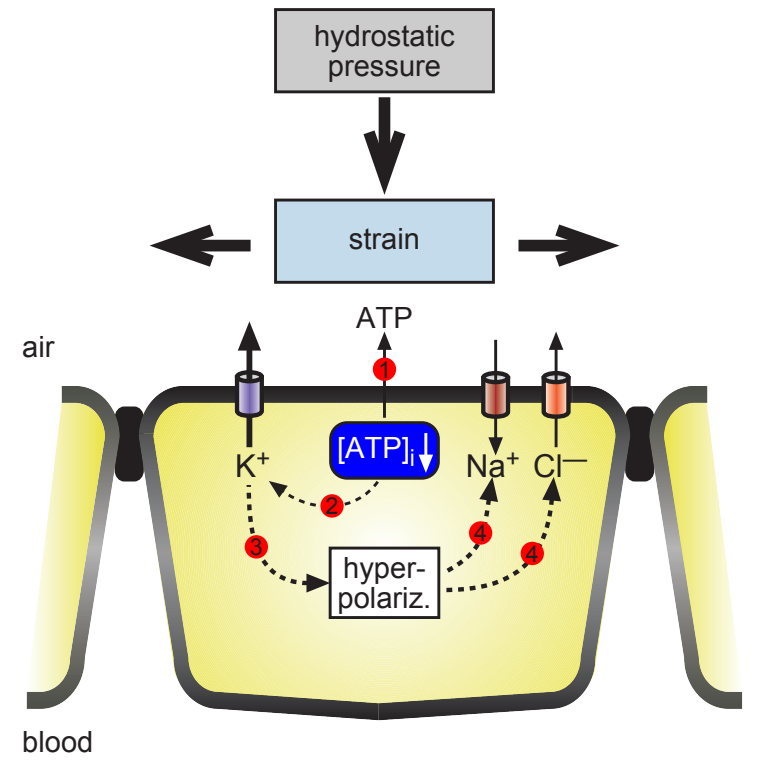

Fig. 7. Scheme illustrating the putative mechanism how hydrostatic pressure acts on epithelial ion transport processes in Xenopus lung epithelium (modified from Bogdan et al., 2008). The entire process could be initiated by the release of ATP via a yet unknown mechanism (1). The decrease of intracellular ATP levels ([ATP $\left.]_{i}\right)$ is likely to activate $K_{\text {ATP }}$ channels (2). This will then cause the cell membrane potential to hyperpolarize (3) and subsequently facilitates the uptake of $\mathrm{Na}^{+}$via apical $\mathrm{Na}^{+}$channels (4) as well as the secretion of $\mathrm{Cl}^{-}$via apical $\mathrm{Cl}^{-}$channels. 
membrane potential (Nichols, 2006) and this in turn enables the possibility to influence the driving forces for other conductances such as $\mathrm{Na}^{+}$and $\mathrm{Cl}^{-}$. From this point of view it might be suggested that strain is primarily transduced in activation of $\mathrm{K}_{\mathrm{ATP}}$ channels and that this in addition influences secondarily $\mathrm{Na}^{+}$and $\mathrm{Cl}^{-}$transport as we observe by the application of hydrostatic pressure on Xenopus lung epithelia. Interestingly, increased ATP levels are also observed in rats ventilated with injurious ventilation parameters. In those experiments the increase of extracellular ATP concentrations was not reasoned by cell damage or cell lysis (Rich et al., 2003). These observations together with our findings indicate that the release of ATP (by a yet unidentified mechanism) might play a key role concerning the activation of ion channels in response to mechanical forces.

Last but not least it might be highlighted that the effect that was observed in response to the application of hydrostatic pressure (inhibition of the ISC) represents a mechanism that impairs ion reabsorption from the alveolar airspace. This will result in a decrease osmotic gradient across the epithelial layer and will subsequently cause a reduction of fluid reabsorption from the airspace. Thus, this is a likely mechanism that impairs the resolution of pulmonary edema or maybe represents a mechanism that - among other incidents initiates the formation of pulmonary edema in response to strain as induced by artificial ventilation.

\section{Conclusions}

The fact that mechanical forces directly affect pulmonary epithelial ion transport is important for future therapeutic options. On the one hand it further confirms the observations that modified ventilation strategies with low pressures and reduced volumes are beneficial for the outcome of patients with respiratory failure that are admitted to artificial ventilation. Therefore, the development of new ventilation strategies should be considered with the background that a minimum of mechanical stress should be used because this decreases interference with ion transport processes and this will preserve the ability of the epithelium for effective ion and water reabsorption.

On the other hand, it offers new therapeutic targets since we have evidence that $\mathrm{K}^{+}$channels and $K_{\mathrm{ATP}}$ channels in particular play a major role in the response observed by increased hydrostatic pressure. In our experiments, the inhibition of these channels has been identified to largely abolish the mechanically induced activation of $\mathrm{K}^{+}$channels and this would be beneficial to prevent the reduced ion transport absorption as that correlates with a decreased water reabsorption from the airspace. Another possibility in order to prevent the effects of strain on ion channels might be represented by the possibility to target the release of ATP, although the mechanisms of ATP release are still under debated.

\section{Acknowledgements}

The work was supported by the Deutsche Forschungsgemeinschaft (grant FR 2124 and the graduate program 455).

\section{References}

ARDS Network Investigators. (2000). Ventilation with lower tidal volumes as compared with traditional tidal volumes for acute lung injury and the acute respiratory 
distress syndrome. The Acute Respiratory Distress Syndrome Network. N Engl J Med, 342(18), 1301-1308, ISSN 0028-4793

Barth, K. \& Kasper, M. (2009). Membrane compartments and purinergic signalling: occurrence and function of P2X receptors in lung. FEBS J, 276(2), 341-353, ISSN $1742-464 X$

Berger, J., Hardt, M., Clauss, W. G. \& Fronius, M. (2010). Basolateral Cl- uptake mechanisms in Xenopus laevis lung epithelium. Am J Physiol Regul Integr Comp Physiol, 299(1), R92-100, ISSN 0363-6119

Berger, J., Richter, K., Clauss, W. G. \& Fronius, M. (2011). Evidence for basolateral Clchannels as modulators of apical Cl- secretion in pulmonary epithelia of Xenopus laevis. Am J Physiol Regul Integr Comp Physiol, 300(3), R616-23, ISSN 0363-6119

Bogdan, R., Veith, C., Clauss, W. \& Fronius, M. (2008). Impact of mechanical stress on ion transport in native lung epithelium (Xenopus laevis): short-term activation of $\mathrm{Na}(+), \mathrm{Cl}(-)$ and $\mathrm{K}(+)$ channels. Pflugers Arch, 456(6), 1109-1120, ISSN 0031-6768

Brainerd, E. L. \& Owerkowicz, T. (2006). Functional morphology and evolution of aspiration breathing in tetrapods. Respir Physiol Neurobiol, 154(1-2), 73-88, ISSN 1569-9048

Bucheimer, R. E. \& Linden, J. (2004). Purinergic regulation of epithelial transport. J Physiol, 555(Pt 2), 311-321, ISSN 0022-3751

Button, B., Picher, M. \& Boucher, R. C. (2007). Differential effects of cyclic and constant stress on ATP release and mucociliary transport by human airway epithelia. $J$ Physiol, 580(Pt. 2), 577-592, ISSN 0022-3751

Caputo, A., Caci, E., Ferrera, L., Pedemonte, N., Barsanti, C., Sondo, E., Pfeffer, U., Ravazzolo, R., Zegarra-Moran, O. \& Galietta, L. J. (2008). TMEM16A, a membrane protein associated with calcium-dependent chloride channel activity. Science, 322(5901), 590-594, ISSN 0036-8075

Chambers, L. A., Rollins, B. M. \& Tarran, R. (2007). Liquid movement across the surface epithelium of large airways. Respir Physiol Neurobiol, 159(3), 256-270, ISSN 15699048

Daniels, C. B. \& Orgeig, S. (2003). Pulmonary surfactant: the key to the evolution of air breathing. News Physiol Sci, 18, 151-157, ISSN 0886-1714

Davis, C. W. \& Lazarowski, E. (2008). Coupling of airway ciliary activity and mucin secretion to mechanical stresses by purinergic signaling. Respir Physiol Neurobiol, 163(1-3), 208-213, ISSN 1569-9048

Dobbs, L. G., Gonzalez, R., Matthay, M. A., Carter, E. P., Allen, L. \& Verkman, A. S. (1998). Highly water-permeable type I alveolar epithelial cells confer high water permeability between the airspace and vasculature in rat lung. Proc Natl Acad Sci $U$ $S$ A, 95(6), 2991-2996, ISSN 0027-8424

Dvorak, A., Tilley, A. E., Shaykhiev, R., Wang, R. \& Crystal, R. G. (2011). Do airway epithelium air-liquid cultures represent the in vivo airway epithelium transcriptome? Am J Respir Cell Mol Biol, 44(4), 465-473, ISSN 1044-1549

Edwards, Y. S. (2001). Stretch stimulation: its effects on alveolar type II cell function in the lung. Comp Biochem Physiol A Mol Integr Physiol, 129(1), 245-260, ISSN 1095-6433

Edwards, Y. S., Sutherland, L. M., Power, J. H., Nicholas, T. E. \& Murray, A. W. (1999). Cyclic stretch induces both apoptosis and secretion in rat alveolar type II cells. FEBS Lett, 448(1), 127-130, ISSN 0014-5793 
Egan, E. A., Nelson, R. M. \& Olver, R. E. (1976). Lung inflation and alveolar permeability to non-electrolytes in the adult sheep in vivo. J Physiol, 260(2), 409-424, ISSN 0022-3751

Fang, X., Fukuda, N., Barbry, P., Sartori, C., Verkman, A. S. \& Matthay, M. A. (2002). Novel role for CFTR in fluid absorption from the distal airspaces of the lung. J Gen Physiol, 119(2), 199-207, ISSN 0022-1295

Fang, X., Song, Y., Hirsch, J., Galietta, L. J., Pedemonte, N., Zemans, R. L., Dolganov, G., Verkman, A. S. \& Matthay, M. A. (2006). Contribution of CFTR to apical-basolateral fluid transport in cultured human alveolar epithelial type II cells. Am J Physiol Lung Cell Mol Physiol, 290(2), L242-9, ISSN 1040-0605

Fewell, J. E., Lee, C. C. \& Kitterman, J. A. (1981). Effects of phrenic nerve section on the respiratory system of fetal lambs. J Appl Physiol, 51(2), 293-297, ISSN 8750-7587

Fischer, H., Van Driessche, W. \& Clauss, W. (1989). Evidence for apical sodium channels in frog lung epithelial cells. Am J Physiol, 256(4 Pt 1), C764-71, ISSN 1040-0605

Fisher, J. L. \& Margulies, S. S. (2002). Na(+)-K(+)-ATPase activity in alveolar epithelial cells increases with cyclic stretch. Am J Physiol Lung Cell Mol Physiol, 283(4), L737-46, ISSN 1040-0605

Folkesson, H. G., Matthay, M. A., Hasegawa, H., Kheradmand, F. \& Verkman, A. S. (1994). Transcellular water transport in lung alveolar epithelium through mercurysensitive water channels. Proc Natl Acad Sci U S A, 91(11), 4970-4974, ISSN 00278424

Frank, J. A. \& Matthay, M. A. (2003). Science review: mechanisms of ventilator-induced injury. Crit Care, 7(3), 233-241, ISSN 1364-8535

Fredberg, J. J. \& Kamm, R. D. (2006). Stress transmission in the lung: pathways from organ to molecule. Annu Rev Physiol, 68, 507-541, ISSN 0066-4278

Fronius, M., Clauss, W. \& Schnizler, M. (2003). Stimulation of transepithelial $\mathrm{Na}(+)$ current by extracellular Gd(3+) in Xenopus laevis alveolar epithelium. J Membr Biol, 195(1), 43-51, ISSN 0022-2631

Hammerschmidt, S., Kuhn, H., Gessner, C., Seyfarth, H. J. \& Wirtz, H. (2007). Stretchinduced alveolar type II cell apoptosis: role of endogenous bradykinin and PI3KAkt signaling. Am J Respir Cell Mol Biol, 37(6), 699-705, ISSN 1044-1549

Homolya, L., Steinberg, T. H. \& Boucher, R. C. (2000). Cell to cell communication in response to mechanical stress via bilateral release of ATP and UTP in polarized epithelia. J Cell Biol, 150(6), 1349-1360, ISSN 0021-9525

Hoschele, S. \& Mairbaurl, H. (2003). Alveolar flooding at high altitude: failure of reabsorption? News Physiol Sci, 18, 55-59, ISSN 0886-1714

Hummler, E., Barker, P., Gatzy, J., Beermann, F., Verdumo, C., Schmidt, A., Boucher, R. \& Rossier, B. C. (1996). Early death due to defective neonatal lung liquid clearance in alpha-ENaC-deficient mice. Nat Genet, 12(3), 325-328, ISSN 1061-4036

Jain, L., Chen, X. J., Ramosevac, S., Brown, L. A. \& Eaton, D. C. (2001). Expression of highly selective sodium channels in alveolar type II cells is determined by culture conditions. Am J Physiol Lung Cell Mol Physiol, 280(4), L646-58, ISSN 1040-0605

Kim, K. J. (1990). Active Na+ transport across Xenopus lung alveolar epithelium. Respir Physiol, 81(1), 29-39, ISSN 0034-5687

Kitterman, J. A. (1996). The effects of mechanical forces on fetal lung growth. Clin Perinatol, 23(4), 727-740, ISSN 0095-5108 
Krebs, H. A. (1975). The August Krogh Principle: "For many problems there is an animal on which it can be most conveniently studied". J Exp Zool, 194(1), 221-226, ISSN 0022$104 \mathrm{X}$

Kunzelmann, K., Kathofer, S., Hipper, A., Gruenert, D. C. \& Gregner, R. (1996). Culturedependent expression of $\mathrm{Na}+$ conductances in airway epithelial cells. Pflugers Arch, 431(4), 578-586, ISSN 0031-6768

Lazrak, A., Thome, U., Myles, C., Ware, J., Chen, L., Venglarik, C. J. \& Matalon, S. (2002). cAMP regulation of $\mathrm{Cl}(-)$ and $\mathrm{HCO}(-)(3)$ secretion across rat fetal distal lung epithelial cells. Am J Physiol Lung Cell Mol Physiol, 282(4), L650-8, ISSN 1040-0605

Lecuona, E., Saldias, F., Comellas, A., Ridge, K., Guerrero, C. \& Sznajder, J. I. (1999). Ventilator-associated lung injury decreases lung ability to clear edema in rats. Am J Respir Crit Care Med, 159(2), 603-609, ISSN 1073-449X

Leipziger, J. (2003). Control of epithelial transport via luminal P2 receptors. Am J Physiol Renal Physiol, 284(3), F419-32, ISSN 1931-857X

Leroy, C., Dagenais, A., Berthiaume, Y. \& Brochiero, E. (2004). Molecular identity and function in transepithelial transport of K(ATP) channels in alveolar epithelial cells. Am J Physiol Lung Cell Mol Physiol, 286(5), L1027-37, ISSN 1040-0605

Liu, M., Tanswell, A. K. \& Post, M. (1999). Mechanical force-induced signal transduction in lung cells. Am J Physiol, 277(4 Pt 1), L667-83, ISSN 1040-0605

Maina, J. N. \& West, J. B. (2005). Thin and strong! The bioengineering dilemma in the structural and functional design of the blood-gas barrier. Physiol Rev, 85(3), 811-844, ISSN 0031-9333

Mall, M., Grubb, B. R., Harkema, J. R., O'Neal, W. K. \& Boucher, R. C. (2004). Increased airway epithelial $\mathrm{Na}+$ absorption produces cystic fibrosis-like lung disease in mice. Nat Med, 10(5), 487-493, ISSN 1078-8956

Matalon, S. \& O'Brodovich, H. (1999). Sodium channels in alveolar epithelial cells: molecular characterization, biophysical properties, and physiological significance. Annu Rev Physiol, 61, 627-661, ISSN 0066-4278

Matsui, H., Grubb, B. R., Tarran, R., Randell, S. H., Gatzy, J. T., Davis, C. W. \& Boucher, R. C. (1998). Evidence for periciliary liquid layer depletion, not abnormal ion composition, in the pathogenesis of cystic fibrosis airways disease. Cell, 95(7), 10051015, ISSN 0092-8674

Matthay, M. A. (2002). Alveolar fluid clearance in patients with ARDS: does it make a difference? Chest, 122(6 Suppl), 340S-343S, ISSN 0012-3692

Matthay, M. A., Folkesson, H. G. \& Clerici, C. (2002). Lung epithelial fluid transport and the resolution of pulmonary edema. Physiol Rev, 82(3), 569-600, ISSN 0031-9333

Matthay, M. A., Fukuda, N., Frank, J., Kallet, R., Daniel, B. \& Sakuma, T. (2000). Alveolar epithelial barrier. Role in lung fluid balance in clinical lung injury. Clin Chest Med, 21(3), 477-490, ISSN 0272-5231

Matthay, M. A., Landolt, C. C. \& Staub, N. C. (1982). Differential liquid and protein clearance from the alveoli of anesthetized sheep. J Appl Physiol, 53(1), 96-104, ISSN 8750-7587

McCray, P. B. J., Bettencourt, J. D., Bastacky, J., Denning, G. M. \& Welsh, M. J. (1993). Expression of CFTR and a cAMP-stimulated chloride secretory current in cultured human fetal alveolar epithelial cells. Am J Respir Cell Mol Biol, 9(6), 578-585, ISSN 1044-1549 
Meban, C. (1973). The pneumonocytes in the lung of Xenopus laevis. J Anat, 114(Pt 2), 235244, ISSN 0021-8782

Morty, R. E., Eickelberg, O. \& Seeger, W. (2007). Alveolar fluid clearance in acute lung injury: what have we learned from animal models and clinical studies? Intensive Care Med, 33(7), 1229-1240, ISSN 0342-4642

Nichols, C. G. (2006). KATP channels as molecular sensors of cellular metabolism. Nature, 440(7083), 470-476, ISSN 0028-0836

Okada, S. F., Nicholas, R. A., Kreda, S. M., Lazarowski, E. R. \& Boucher, R. C. (2006). Physiological regulation of ATP release at the apical surface of human airway epithelia. J Biol Chem, 281(32), 22992-23002, ISSN 0021-9258

Olivier, R., Scherrer, U., Horisberger, J. D., Rossier, B C. \& Hummler, E. (2002). Selected contribution: limiting $\mathrm{Na}(+)$ transport rate in airway epithelia from alpha-ENaC transgenic mice: a model for pulmonary edema. J Appl Physiol, 93, 1881-1887, ISSN 8750-7587

Olver, R. E., Davis, B., Marin, M. G. \& Nadel, J. A. (1975). Active transport of Na+ and Clacross the canine tracheal epithelium in vitro. Am Rev Respir Dis, 112(6), 811-815, ISSN 0003-0805

Plataki, M. \& Hubmayr, R. D. (2010). The physical basis of ventilator-induced lung injury. Expert Rev Respir Med, 4(3), 373-385, ISSN 1747-6348

Ricard, J. D., Dreyfuss, D. \& Saumon, G. (2003). Ventilator-induced lung injury. Eur Respir J Suppl, 42, 2s-9s, ISSN 0904-1850

Rich, P. B., Douillet, C. D., Mahler, S. A., Husain, S. A. \& Boucher, R. C. (2003). Adenosine triphosphate is released during injurious mechanical ventilation and contributes to lung edema. J Trauma, 55(2), 290-297, ISSN 0022-5282

Riordan, J. R., Rommens, J. M., Kerem, B., Alon, N., Rozmahel, R., Grzelczak, Z., Zielenski, J., Lok, S., Plavsic, N., Chou, J. L. \& et, a. (1989). Identification of the cystic fibrosis gene: cloning and characterization of complementary DNA. Science, 245(4922), 1066-1073, ISSN 0036-8075

Rogers, C. S., Stoltz, D. A., Meyerholz, D. K., Ostedgaard, L. S., Rokhlina, T., Taft, P. J., Rogan, M. P., Pezzulo, A. A., Karp, P. H., Itani, O. A., Kabel, A. C., WohlfordLenane, C. L., Davis, G. J., Hanfland, R. A., Smith, T. L., Samuel, M., Wax, D., Murphy, C. N., Rieke, A., Whitworth, K., Uc, A., Starner, T. D., Brogden, K. A., Shilyansky, J., McCray, P. B. J., Zabner, J., Prather, R. S. \& Welsh, M. J. (2008). Disruption of the CFTR gene produces a model of cystic fibrosis in newborn pigs. Science, 321(5897), 1837-1841, ISSN 0036-8075

Roux, E. (2002). [Origin and evolution of the respiratory tract in vertebrates]. Rev Mal Respir, 19(5 Pt 1), 601-615, ISSn 0761-8425

Rubin, B. K. (2002). Physiology of airway mucus clearance. Respir Care, 47(7), 761-768, ISSN 0020-1324

Sackin, H. \& Boulpaep, E. L. (1975). Models for coupling of salt and water transport; Proximal tubular reabsorption in Necturus kidney. J Gen Physiol, 66(6), 671-733, ISSN 0022-1295

Sanchez-Esteban, J., Tsai, S. W., Sang, J., Qin, J., Torday, J. S. \& Rubin, L. P. (1998). Effects of mechanical forces on lung-specific gene expression. Am J Med Sci, 316(3), 200-204, ISSN 0002-9629 
Schroeder, B. C., Cheng, T., Jan, Y. N. \& Jan, L. Y. (2008). Expression cloning of TMEM16A as a calcium-activated chloride channel subunit. Cell, 134(6), 1019-1029, ISSN 00928674

Smith, P. L., Welsh, M. J., Stoff, J. S. \& Frizzell, R. A. (1982). Chloride secretion by canine tracheal epithelium: I. Role of intracellular c AMP levels. J Membr Biol, 70(3), 217226, ISSN 0022-2631

Sommer, D., Bogdan, R., Berger, J., Peters, D. M., Morty, R. E., Clauss, W. G. \& Fronius, M. (2007). CFTR-dependent Cl- secretion in Xenopus laevis lung epithelium. Respir Physiol Neurobiol, 158(1), 97-106, ISSN 1569-9048

Stoltz, D. A., Meyerholz, D. K., Pezzulo, A. A., Ramachandran, S., Rogan, M. P., Davis, G. J., Hanfland, R. A., Wohlford-Lenane, C., Dohrn, C. L., Bartlett, J. A., Nelson, G. A. t., Chang, E. H., Taft, P. J., Ludwig, P. S., Estin, M., Hornick, E. E., Launspach, J. L., Samuel, M., Rokhlina, T., Karp, P. H., Ostedgaard, L. S., Uc, A., Starner, T. D., Horswill, A. R., Brogden, K. A., Prather, R. S., Richter, S. S., Shilyansky, J., McCray, P. B. J., Zabner, J. \& Welsh, M. J. (2010). Cystic fibrosis pigs develop lung disease and exhibit defective bacterial eradication at birth. Sci Transl Med, 2(29), 29ra31, ISSN 1946-6234

Sznajder, J. I. (2001). Alveolar edema must be cleared for the acute respiratory distress syndrome patient to survive. Am J Respir Crit Care Med, 163(6), 1293-1294, ISSN 1073-449X

Tarran, R., Button, B. \& Boucher, R. C. (2006). Regulation of normal and cystic fibrosis airway surface liquid volume by phasic shear stress. Annu Rev Physiol, 68, 543-561, ISSN 0066-4278

Tarran, R., Button, B., Picher, M., Paradiso, A. M., Ribeiro, C. M., Lazarowski, E. R., Zhang, L., Collins, P. L., Pickles, R. J., Fredberg, J. J. \& Boucher, R. C. (2005). Normal and cystic fibrosis airway surface liquid homeostasis. The effects of phasic shear stress and viral infections. J Biol Chem, 280(42), 35751-35759, ISSN 0021-9258

Tizzano, E. F., O'Brodovich, H., Chitayat, D., Benichou, J. C. \& Buchwald, M. (1994). Regional expression of CFTR in developing human respiratory tissues. Am J Respir Cell Mol Biol, 10(4), 355-362, ISSN 1044-1549

Ussing, H. H. \& Zerahn, K. (1951). Active transport of sodium as the source of electric current in the short-circuited isolated frog skin. Acta Physiol Scand, 23(2-3), 110-127, ISSN 0001-6772

Verkman, A. S. (2007). Role of aquaporins in lung liquid physiology. Respir Physiol Neurobiol, 159(3), 324-330, ISSN 1569-9048

Verkman, A. S., Matthay, M. A. \& Song, Y. (2000). Aquaporin water channels and lung physiology. Am J Physiol Lung Cell Mol Physiol, 278(5), L867-79, ISSN 1040-0605

Ware, L. B. \& Matthay, M. A. (2000). The acute respiratory distress syndrome. N Engl J Med, 342(18), 1334-1349, ISSN 0028-4793

Ware, L. B. \& Matthay, M. A. (2001). Alveolar fluid clearance is impaired in the majority of patients with acute lung injury and the acute respiratory distress syndrome. Am J Respir Crit Care Med, 163(6), 1376-1383, ISSN 1073-449X

Welsh, M. J. (1987). Electrolyte transport by airway epithelia. Physiol Rev, 67(4), 1143-1184, ISSN 0031-9333

Welsh, M. J. \& Smith, A. E. (1993). Molecular mechanisms of CFTR chloride channel dysfunction in cystic fibrosis. Cell, 73(7), 1251-1254, ISSN 0092-8674 
Widdicombe, J. H. \& Welsh, M. J. (1980). Ion transport by dog tracheal epithelium. Fed Proc, 39(13), 3062-3066, ISSN 0014-9446

Widdicombe, J. H., Welsh, M. J. \& Finkbeiner, W. E. (1985). Cystic fibrosis decreases the apical membrane chloride permeability of monolayers cultured from cells of tracheal epithelium. Proc Natl Acad Sci U S A, 82(18), 6167-6171, ISSN 0027-8424

Willumsen, N. J., Davis, C. W. \& Boucher, R. C. (1989). Intracellular Cl- activity and cellular Cl- pathways in cultured human airway epithelium. Am J Physiol, 256(5 Pt 1), C1033-44, ISSN 0002-9513

Wirtz, H. R. \& Dobbs, L. G. (2000). The effects of mechanical forces on lung functions. Respir Physiol, 119(1), 1-17, ISSN 0034-5687

Yang, Y. D., Cho, H., Koo, J. Y., Tak, M. H., Cho, Y., Shim, W. S., Park, S. P., Lee, J., Lee, B., Kim, B. M., Raouf, R., Shin, Y. K. \& Oh, U. (2008). TMEM16A confers receptoractivated calcium-dependent chloride conductance. Nature, 455(7217), 1210-1215, ISSN 0028-0836 


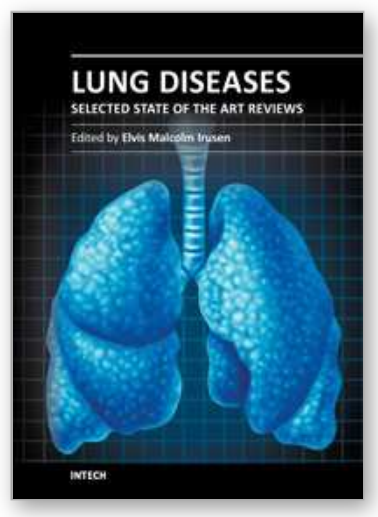

\section{Lung Diseases - Selected State of the Art Reviews}

Edited by Dr. Elvisegran Malcolm Irusen

ISBN 978-953-51-0180-2

Hard cover, 690 pages

Publisher InTech

Published online 02, March, 2012

Published in print edition March, 2012

The developments in molecular medicine are transforming respiratory medicine. Leading clinicians and scientists in the world have brought their knowledge and experience in their contributions to this book. Clinicians and researchers will learn about the most recent advances in a variety of lung diseases that will better enable them to understand respiratory disorders. This treatise presents state of the art essays on airways disease, neoplastic diseases, and pediatric respiratory conditions. Additionally, aspects of immune regulation, respiratory infections, acute lung injury/ARDS, pulmonary edema, functional evaluation in respiratory disorders, and a variety of other conditions are also discussed. The book will be invaluable to clinicians who keep up with the current concepts, improve their diagnostic skills, and understand potential new therapeutic applications in lung diseases, while scientists can contemplate a plethora of new research avenues for exploration.

\section{How to reference}

In order to correctly reference this scholarly work, feel free to copy and paste the following:

Martin Fronius (2012). Mechanical Forces Impair Alveolar Ion Transport Processes - A Putative Mechanism Contributing to the Formation of Pulmonary Edema, Lung Diseases - Selected State of the Art Reviews, Dr. Elvisegran Malcolm Irusen (Ed.), ISBN: 978-953-51-0180-2, InTech, Available from:

http://www.intechopen.com/books/lung-diseases-selected-state-of-the-art-reviews/mechanical-forces-impairalveolar-ion-transport-processes-a-putative-mechanism-contributing-to-the-f

\section{INTECH}

open science | open minds

\section{InTech Europe}

University Campus STeP Ri

Slavka Krautzeka 83/A

51000 Rijeka, Croatia

Phone: +385 (51) 770447

Fax: +385 (51) 686166

www.intechopen.com

\section{InTech China}

Unit 405, Office Block, Hotel Equatorial Shanghai

No.65, Yan An Road (West), Shanghai, 200040, China

中国上海市延安西路65号上海国际贵都大饭店办公楼405单元

Phone: +86-21-62489820

Fax: $+86-21-62489821$ 
(C) 2012 The Author(s). Licensee IntechOpen. This is an open access article distributed under the terms of the Creative Commons Attribution 3.0 License, which permits unrestricted use, distribution, and reproduction in any medium, provided the original work is properly cited. 